\title{
DECOLONIZING AFRICAN STUDIES: LOOKING INTO THE GAPs
}

\author{
Luce Beeckmans
}

Department of Architecture and Urban Planning, Ghent University, Belgium

This special issue of Afrika Focus brings together a selection of keynotes delivered at the international symposia of the Ghent Africa Platform (the so-called GAPSYMs), as well as a number of the Mandela Lectures organised by the Ghent Africa Platform (GAP) (for an overview, see Table I). ${ }^{\mathrm{I}}$ The motivation for compiling these papers was the roth anniversary of GAP in 2017. The Africa Platform is one of the oldest UGent regional platforms, bringing together all relevant expertise at Ghent University concerning the African continent, and fostering academic collaboration with African universities. In 2017 we also celebrated the 3oth anniversary of the scientific journal Afrika Focus, which is closely linked to, but predates GAP by more than 20 years. As this special issue aims to give an insight into GAP's scientific activities over the past decade, also the former and current (vice-)presidents of GAP were invited to write an article: respectively Marleen Temmerman \& Karel Arnaut and Patrick Van Damme \& Johan Lagae, who was replaced by Kristien Michielsen in 2018. They were asked to contribute papers in which they reflect on the past ro years of GAP, departing from their own research interests. In addition, we invited the Congolese photographer Sammy Baloji, who participated in GAPSYM 4 ([Un] disciplined encounters), to develop a visual essay together with Filip De Boeck, making the special issue indeed something special.

At the symbolic roth GAPSYM (Celebrating partnership with Africa), held in 2016, the South African scholar Premesh Lalu gave a thought-provoking keynote lecture, which opens this special issue. Lalu's keynote is a convincing plea to decolonize African Studies following a new pathway, 'one that will give to Europe an escape from the inheritance of Eurocentrism as it will give to Africa its place in a planetary library' (p.20). When I started my work as guest editor in 2017 by contacting the potential contributors to this special 
GAPSYM $1 \mid 2007$

Heritage and/as reproduction in Africa. Outcomes and limits

GAPSYM 2 | 2008

Mobilities in Africa - Africa in mobility

GAPSYM3 2009

Gendering research in/on Africa

GAPSYM 4|2010, Brussels

[un]disciplined encounters: science as terrain of postcolonial interaction between Africa and Europe - past and future

GAPSYM $5 \mid 2011$

(r)Urban Africa: multidisciplinary approaches to the African city

GAPSYM 6| 2012

Africa: (post-) development?

GAPSYM 7| 2013

Africa and Food: challenges, risks and opportunities

GAPSYM $8 \mid 2014$

Colonial memories at present: decolonizing Belgium?

GAPSYM $9 \mid 2015$

Trading places: The role of trade with Africa

GAPSYM $10 \mid 2016$

Celebrating partnership with Africa: Demonstrating the value of international collaboration on teaching and research

GAPSYM $11 \mid 2017$

Health in Africa - an interdisciplinary approach

GAPSYM $12 \mid 2018$ | September

GAP hosts Tropentag 2018

\section{Mandela Lectures (in Ghent, November)}

Mandela Lecture $1 \mid 2014$

Lecture by Prof. Brian O'Connell: Global challenges for universities in a North-South context

Mandela Lecture 2 | 2015

Lecture by Prof. lain Low: Space and transformation. Architecture in an age of radical transformation

Mandela Lecture $3 \mid 2016$

Albie Sachs in conversation with Eva Brems

Mandela Lecture $4 \mid 2017$

Tom Lanoye in conversation with Antjie Krog about the role of Nelson Mandela in South Africa and the world today

Mandela Lecture $5 \mid 2018$

Lecture by Zelda La Grange: Nelson Mandela - the legacy

Table 1: Overview of GAPSYMS and Mandela Lectures. 
issue, Lalu's keynote was given to them as an invitation to be self-reflexive about their work when (re-)writing their keynote talk into an article. Yet, Lalu's keynote also provides a good background for reflecting on (the production process of) this special issue, and more generally on GAP's scientific activities in the last ro years. The following words of Lalu are especially inspirational in this respect: 'In pursuing new relations of research across hemispheres, we may need to rearticulate not only what is absent from our discourse, but rather the latent content that remains stubbornly unseen in what we see' (p.22).

I have been involved in GAP since GAPSYM2 (Mobilities in Africa - Africa in mobility) in 2008. At that time, I participated with a poster presentation. This first presentation evolved into a lengthy association that has given me quite a good insider perspective. But even so, diving into the GAP archive from the last Io years to compile this special issue has been particularly enlightening, but of course the intention was not to establish a complete genealogy of GAP. The outcome of my fairly intense efforts to track down keynote speakers and convince them to publish their texts, considering the fact that it was even for them often difficult to retrace their own papers - or sometimes even remember they had even been at a GAP symposium, is well summarized in the table of contents of this special issue. There is much to learn from this table of contents, but also from what is not in it, to refer back to Lalu's keynote, both when it comes to the merits and gaps of GAP. In the following I will discuss this in more detail.

If we consider the table of contents, we see that this special issue presents an engaging collection of texts from a wide array of disciplinary fields on topics such as (urban) development, African culture, African diaspora, health care and agriculture. This clearly represents the wide variety of topics GAP has been tackling at its events, and this from very interdisciplinary perspectives. I believe GAP can be proud of having hosted so many interesting and influential scholars over the last ten years, as well as being presided over by a team of committed and prominent academics. We are extremely delighted to have their contributions in this special issue, which is in fact also a book publication, something the special cover reveals. Two of the keynotes are not represented here by their keynote talk as such, but by a review of their work, as they either lacked the time to revise their keynote, or because it had been published already elsewhere.

Some contributors, amongst whom the two authors of the reviews, responded well to my call to keep the decolonisation debate in mind during their writing and did an outstanding job in being self-reflexive about their work and its position within African Studies. Other scholars replied that their research was 'more orientated towards the future', or that their research area 'has never been a colony'. This demonstrates that 'decolonisation' has not yet become a generally understood and well-established concept within the broader field of African Studies, particularly not in certain parts of the world and in certain scientific domains - again stressing the importance of universality and interdisciplinarity when it comes to our attempt to 'decolonize' the field. ${ }^{2}$ 


\begin{tabular}{|r|l|l|l|l|l|}
\cline { 2 - 6 } \multicolumn{1}{l|}{} & Authors & Sex author & Nationality author & Research area & Involvement \\
\hline 1 & Luce Beeckmans & Female & Belgium & $/$ & Guest editor \\
\hline 2 & Premesh Lalu & Male & South Africa & South Africa & Keynote GAPSYM 10 \\
\hline 4 & Ray Bush & Male & United Kingdom & $/$ & Keynote GAPSYM 6 \\
\hline 5 & Albie Sachs & Male & USA & Tanzania & Keynote GAPSYM 5 \\
\hline 6 & lain Low & Male & South Africa & South Africa & Mandela Lecture 3 \\
\hline 7 & Johan Lagae & Male & South Africa & South Africa & Mandela Lecture 1 \\
\hline 8 & Marleen Temmerman & Male & Belgium/ & DRCongo & Vice-president GAP \\
\hline 9 & Patrick Van Damme & Male & Belgium & / & \\
\hline 10 & Tesfaalem G. Asfaha et al. & Male & Ethiopia/ Belgium & Ethiopia & Keynote GAPSYM 10 \\
\hline 11 & Karel Arnaut & Male & Belgium & / & Vice-president GAP, \\
\hline 12 & Lye Mudaba Yoka & Male & DRCongo & DRCongo & GAPSYM 4 \\
\hline 13 & Patrick Mudekereza & Male & DRCongo & DRCongo & GAPSYM 4 \\
\hline 14 & $\begin{array}{l}\text { Sammy Baloji } \\
\text { \& Filip De Boeck }\end{array}$ & Male & DRCongo & DRCongo & GAPSYM 4 \\
\hline 16 & Gillian Matthys & Male & Belgium & / & Keynote GAPSYM 11 \\
\hline
\end{tabular}

/ = no single country focus

Table 2: Interpreting this special issue of Afrika Focus.

It is precisely within this decolonizing spirit that there must be some room for critical remarks, even in this anniversary issue (for an overview, see Table 2). Firstly, it becomes very clear from the table of contents that women are severely underrepresented in this special issue. Out of 16 contributions, only 3 stem from a female author, namely this editorial, one of the reviews and the article from the former GAP president Marleen Temmerman. Indeed, looking back at all the GAPSYM programmes, GAP has had almost no female keynotes over the last Io years. To complicate the matter even further, I could not find anyone from GAPSYM 3 (Gendering research in/on Africa) available to contribute to this issue. Considering the fact that a significant number of women are active within African Studies, I believe it is our task, if we ever want to break the glass ceiling in academia, to more actively engage them, this includes as keynote speakers on our GAPSYMs or as Mandela Lecturers.

Secondly, half of the contributors to this special issue are African. This in itself is an accomplishment, considering the fact that it was particularly difficult to retrace the African keynotes of the GAPSYMs: their email-addresses no longer functioned or they could

stand-the-decolonisation-debate-heres-your-reading-list-51279. A (non-exhaustive) list of interesting Africanauthored academic studies on Africa can be consulted here: http://democracyinafrica.org/decolonising-theuniversity-the-african-politics-reading-list/ 
not be found on the web. Sometimes I lost track of them after an initial contact and felt compelled to use my network to bring them back into the project (mostly via old school telephone contact). My endeavours were, however, not always very fruitful. In order to have enough African voices included in this issue - which is the essence of what 'decolonisation' truly heralds - I decided to contact a number of African participants to the GAPSYMs who were not keynotes as such (especially those working in the cultural sphere, a prime area of African empowerment). Yet, compared to how easy it was to get in touch with the non-African keynotes, I can only conclude that there is still a sharp divide to overcome in terms of researchers' visibility and approachability. Moreover, it is important to note that in this special issue we have contributions from African scholars from only three (out of 54) African countries: Ethiopia, DRCongo (a former Belgian colony, hence a strong postcolonial link) and South Africa (a country with a specific status within the continent also on an academic level). Hence, GAP is reaching only a very small range of nationalities, and the ones that we reach are very dependent on personal networks of the members of the board of GAP. Consequently, in some ways decolonization still has to start and certainly when it comes to involving scholars from Africa at our symposia and in our publications. More than ever, certainly in terms of accessibility, it seems time to finally put our ideas into practice and organize a GAPSYM on African soil. Meanwhile, more funding to cover travel costs for Africans to come to Ghent is necessary, as well as more encouragement and guidance for Africans to publish in Afrika Focus, taking into consideration the uneven access to academic resources.

Thirdly, the African countries or regions on which the articles, apart from the more general ones, focus, seem fairly representative of the areas where UGent researchers, and so GAP, are working: East Africa, with a prime focus on Ethiopia, Kenya and Tanzania; Central Africa with a prime focus on DRCongo; and South Africa, hence only five countries. It is difficult therefore not to notice that West Africa is completely missing from this special issue. More generally, I observed that French contributions are rare at the GAP symposia, with the possible exception of the successful special edition of GAPSYM 4 in Brussels. This is another working point, as French speaking areas in Africa seem doubly neglected in the Anglo-Saxon and Euro-American dominated academic world. Precisely because of this, and perhaps as opposed to current developments in academia, I would make a plea to keep the journal of Afrika Focus bilingual in the future, and possibly also add a French website for the submission of papers.

It is of course not entirely clear to what extent the above observations are representative for all the GAPSYMs and Mandela Lectures, let alone for the entire functioning of GAP or the complete Afrika Focus archive from the last 30 years - this was not the objective of my exercise. Yet, it is obvious that there is still much work ahead of us to 'decolonize African Studies', even within our own platform - even though it has always been the prime mission of GAP to criticize stubborn and longstanding stereotypes about the African continent. I strongly believe that some of the articles in this special issue will elicit a deeper sense of awareness in that sense. Moreover, I hope that my recommendations will be an inspiration to draw from in the future while rethinking GAP. It is only by continuously 
questioning the ways 'we define, distribute, and also deny, knowledge' through our own research, that we will be able to break with the legacies of exclusion and oppression (instead of reinforcing them often unconsciously). ${ }^{3}$ It is also only in this way that 'decolonisation' will not become another façade for continuing what we already have been doing for decades, for instance within the framework of development cooperation (instead of fully-fledged international collaboration on equal grounds and without paternalistic motives). Ultimately, the fundamental question 'For whom do we research Africa and for what purpose?' always deserves legitimate answers. ${ }^{4}$

By now it has become evident that this is not a special issue replete in self-praise, which is well reflected in the title 'Decolonizing African Studies: celebrating and rethinking Io years of GAP'. Indeed, self-glorification has never been the spirit of GAP. Rather it is one of critical (self-)reflection with the aim of (scientific) betterment.

Finally, this is also the place to sincerely thank everyone who has, in one way or another, contributed to GAP in the past and those who will in the future. In particular we have to thank the GAP coordinators Annelies Verdoolaege and Dominique Godfroid. GAP would simply not exist without their driving force. In fact, as has often been the case during the GAP events, these two (female) persons are quite invisible in this special issue. Also here we might seek to decolonise the minds a little more, in particular because their commitment is far-reaching and transformative. An example of their behind-thescenes engagement is their well appreciated involvement in the International Students Conference organised at Ghent University in November 2018. It is at this kind of occasion that we can see a new generation of self-confident Africans who, perhaps steered by the \#RhodesMustFall campaign in South Africa, will no longer tolerate the structural inequalities deeply embedded in the academic system, and in the production of knowledge more generally, both in Africa and in the West. A special thanks furthermore goes to David Chan for tirelessly proof-reading our texts over the last decade and to Filip Erkens for taking care of the lay-out and design of our journal.

Thanks to all of you and please enjoy this very special edition of Afrika Focus. ty of Edinburgh, Centre of African Studies \& Global Development Academy, 20r6; The Conference 'African Mobilities - Reshaping narratives and practices of circulation and exchange', The Nordic Africa Institute, Uppsala, Sweden, I9-2I September 2018; the call for paper proposals on 'decolonizing curricula' for the African Studies Association Conference, forthcoming in November 2018; the call for papers 'Decolonizing the Academy' for the special issue of Critical African Studies (forthcoming); the recently published special issue 'Decolonizing African Studies', African Studies Review, vol. 6I no. 3, September 20I8, pp. I-7. 